\title{
VALUE BASED MANAGEMENT IN THE NEW ECONOMY
}

\author{
Cozmiuc Diana \\ West University, Timișoara, Romania \\ diana.cozmiuc.record@gmail.com \\ Petrișor loan \\ West University, Timișoara, Romania \\ ipetrisor53@yahoo.fr
}

\begin{abstract}
The main objective of this paper is to investigate the updates brought by the New Economy, especially new business models brought by digitalization, on value-based management. This objective is to see if classic valuebased management and the updates brought by the New Economy conflict or are somehow harmonized or complementary. Another objective is to illustrate the updates brought by digitalization as case object on Siemens as case subject. The paper is focused on value-based management particularities for digitalization products, services, solutions. The context of the paper is digitalization technology and its impact on business and society, digital transformation. The phenomenon is new to society in all and therefore both literature review and case studies are highly relevant. The article is a case study on a top European corporation, both leader in digitalization and excellent value-based management practitioner. The case study is exploratory and descriptive, searching for the connections between digitalization and value. It relies on secondary evidence about Siemens. The questions are how New Economy value patterns work in practice and how do they relate to classic value indicators, net present value of discounted cash flow or its equivalent Economic Value Added. The paper finds a connection between innovation lifecycle and investment approval or capital budgeting. The beginning of the project lifecycle involves investment in intangible assets, business models, an open network structure and is funded by venture capital. As the idea matures close to customer contract negotiation stages, the network structure turns into a project budgeted via program management and equity and debt. The findings show how so-called new capital budgeting methods, venture capital, are reconciled with classic value-based management using equity and debt and Economic Value-Added investment appraisal. Both funding methods have their logic and place in idea lifecycle at Siemens. The paper finds a match between the lean start-up method and early stages of digital offering lifecycle, and a complementarity between venture capital funding methods and equity and debt capital funding methods given by the innovation lifecycle.
\end{abstract}

Keywords: digitalization, intangible assets, customer value proposition, key performance indicators, venture capital

\section{INTRODUCTION AND METHODOLOGY}

Business excellence may be defined as measuring business performance improvements and value creation dynamics (Emerald, 2020), and Siemens is a classic case example for business excellence 
(Zhao, 2004) to be tested in the New Economy. This paper illustrates how Siemens reconciles Economic Value Added with digitalization in a simple coherent approach that is tied to several other articles from the same author. The main objective of this paper is to investigate the updates brought by the New Economy, especially new business models brought by digitalization, on value-based management via value drivers. This means is to see if classic value-based management and the updates brought by the New Economy conflict or are somehow harmonized or complementary. A second objective is to describe Siemens' digitalization strategy, that is digital technology and their impact on key performance indicators or value drivers. The paper aims to illustrate recent practices such as the internal start-up, using business models and funding business models and network structures with venture capital on the Siemens case example, a pioneer in all these practices. The framework for this case study is the theoretical and empirical definition for digitalization at Siemens. In the literature review, digitalization is defined (CapGemeni, 2013; Gartner, 2019; The Global Center for Business Transformation, 2019a, 2019b; IBM Institute for Business Value, 2011; IDC, 2017a) as the use of digital technologies to change a business model and provide valuecreating opportunities or improve performance quantifiably. Siemens defines digitalization as leveraging digital technology for concrete customer benefits, such as key performance indicators. The two definitions sum up to digitalization as the use of digital technology to improve performance quantifiably, via key performance indicators. The methodology of this article is to explore, analyze and then synthesize the key value drivers and related decisions in Siemens' digitalization strategy. The context of this article is digitalization and the updates digitalization bring to value based management, especially replacing planning funded by equity with business models funded by venture capital, in theory and practice. The object of the study comprises the updates brought by digitalization on value-based management: widespread of value drivers or performance indicators, using business models, start-up organizational structures, funding business models with venture capital. The subject of the case is a prominent valuebased management practitioner and digitalization product, service or solution supplier. The article is an exploratory and descriptive case study. It explores the validity of classic value-based management, via the continuity of Economic Value Added and the updates brought by the New Economy, such as funding business models with venture capital. The descriptive case study refers to Siemens' digitalization strategy, leveraging digital technology for concrete customer benefits. The data from Siemens is secondary, refers to annual reports, online presentation and articles and is part of a much wider research he highlights of which were included in this article. The data was explored based on its relation to digitalization strategy, digital technology, customer value proposition, and related processes. The data was explored, analyzed to begin with. The pattern of the empirical case is induced based on Siemens' digitalization strategy overview cited and referenced in the article. The paper has several important findings. The main one is that 
Siemens' digitalization strategy systematically comprises investment in intangible assets to deliver concrete customer value proposition. Intangible assets and customer value proposition are illustrated in detail in the article. The paper also finds this investment is related to the ideation stage in the innovation life cycle, is placed in networks especially start-ups, is funded using business models specially to shape the customer value proposition and funded by venture capital. This is where the Siemens theoretical example matches the literature review. As a complementary finding, as the product lifecycle advances to maturity and customer negotiations, the customer value proposition is enclosed in customer contracts and basis for this negotiation, and the open network structure funded by venture capital shifts to already classic project management overviewed by program offices, planning, use of Economic Value Added or discounted cash flow to fund equity or debt capital. This answers the goal of the article, to check if the updates brought by the New Economy reconcile or conflict with classic value-based management. The Siemens answer is to use intangible assets funded by venture capital via business models at the beginning of the innovation lifecycle and include this in the Economic Value-Added overarching framework as later stages of the ideation lifecycle are reached. This research is limited by available space and therefore challengeable with respect to the consideration of individual topics both in the literature review and empirical data analysis sections.

\section{LITERATURE REVIEW}

\subsection{Macroeconomic context: the shift from the industrial economy to the new economy}

The Industrial Economy is transforming in the Knowledge Economy in several progressive stages. Digital technology has inflicted several waves of fast and high-scale change to the Industrial Economy (IBM Institute for Value, 2011; IDC, 2017a). These changes may be represented as the decades of the Knowledge Economy (IBM Institute for Business Value, 2011): in the 1990s, the emergence of the Knowledge Economy, with digital products and infrastructure; in the 2000s, digital distribution and web strategy; since 2010, digital transformation of business models.

Digital technology, created by digitization, may be defined as the IDC's third platform. The third platform comprises cloud, big data analytics, social business, mobility and technology accelerators which consist of robotics, natural interfaces, 3D printing, Internet of Things, cognitive systems, next generation security (IDC, 2017b). Digital technology may bear different names and classifications. For example, digitalization technology in manufacturing is called Industry 4.0 or the Industrial Internet and comprises big data and analytics, autonomous robots, simulation, vertical and horizontal integration, Industrial Internet of Things, 
cyber security, cloud, additive manufacturing, augmented reality (Boston Consulting Group, 2015). Digitalization technology transforms individual industries (World Economic Forum, 2019).

Digitalization is defined (CapGemeni, 2013; Gartner, 2019; The Global Center for Business Transformation, 2019a, 2019b; IBM Institute for Business Value, 2011; IDC, 2017a) as the use of digital technologies to change a business model and provide value-creating opportunities or improve performance quantifiably. According to IBM (2011), digital transformation is the pervasive degree of economic impact digital technology has on functions, industries, society. IDC (2017a) describes digital transformation as the use of digital technologies in ways that were never anticipated. Innovations driven by digital technologies are expected to bring about unprecedented business transformation, representing the biggest industry shakeout since the Industrial Revolution. According to Accenture (2019), digital transformation turns every business into a digital business. Companies face the digital imperative to harness the power of digital technologies to become more effective, innovative and disruptive. Cisco (2019) defines digital transformation as the application of technology to build new business models, processes, software, and systems that results in more profitable revenue, greater competitive advantage, and higher efficiency. According to IScoop (2019), digital transformation is the profound transformation of business and organizational activities, processes, competencies and models to fully leverage the changes and opportunities of a mix of digital technologies and their accelerating impact across society in a strategic and prioritized way, with present and future shifts in mind. The Global Center for Digital Business Transformation (2019a, 2019b) identifies and defines digital business transformation as a journey to adopt and deploy digital technologies and business models to improve performance quantifiably. Digital transformation (CapGemeni, 2013) is the use of technology to radically improve performance or reach of enterprises - via change customer relationships, internal processes, and value propositions, the blocks of digital transformation. These blocks of digital transformation may be used to assess digital maturity. The emergence of the New Economy at all stages has brought volatility, uncertainty, complexity and ambiguity (Berinto, 2014a, 2014b; Bennet and Lemoine, 2014).

\subsection{Value driver definition and the relationship to value decisions and value indicators}

In value-based management, value drivers are the factors which create shareholder or stakeholder value in the generic formulas of value indicators. In the 1990s, several consultancy firms engaged in the war of metrics and proposed several value indicators: Shareholder Value Added for LEK Consulting (Rappaport, 1986), Economic Value Added for Stern and Stewart (Stewart, 1991), CFROI for Holt Associates (Madden, 1999, 2010), Cash Value Added for Holt Associates (Madden, 1999, 2010) or Boston Consulting Group (Boston Consulting Group, 2008), Total Shareholder Return for Boston Consulting Group (Boston 
Consulting Group, 2008). In value-based management, value drivers may also be defined as the objectives of company decisions in creating long term and short-term shareholder value. In Rappaport's approach in 1986, value drivers are the objectives of competitive advantage, operational, investment and financing decisions that create Shareholder Value Added on the long run (Rappaport, 1986). Value drivers are the duration of competitive advantage; sales growth, operating profit margin, income tax rate for operational decisions; fixed capital investment and working capital investment for investment decisions; equity and debt in the cost of capital (Rappaport, 1986). In this view, strategic decisions refer to the longterm and involve capital allocation (investment and financing decisions and related value drivers) for future operations. According to Mc Kinsey's approach since 1994 (Copeland et al, 1994, 2000; Koller et al, 2005, 2010a, 2010b, 2015), value drivers are decisions' objectives to create value to be measured when strategy is executed. Value drivers are performance indicators and managing value drivers is performance management. Value drivers also form the link between strategy and a company's intrinsic value on capital markets. Valuation bridges strategic management and financial management. In this view, strategy is the long-term value driver and as strategy is progressively implemented, value drivers become shorter term oriented and achieve value. In the Balanced Scorecard (Kaplan and Norton, 1992), value drivers are learning and growth, internal perspective, customer perspective key performance indicators that create future value represented by financial key performance indicators. In strategic management, value drivers are driven from strategy, refer to the future and are used to value and implement strategy (Arnold, 1998; Black et al, 1998; Kaplan and Norton, 1992, 2004; KPMG, 1999; Leahy, 2000; Martin and Petty, 2000; McTaggart et al, 1994). In valuation (Wendee, 2011), value drivers are defined as any variable that impacts a company's value to potential buyers and may constitute a large list in an extensive literature review. Across value-based management 1990s literature and as in the Balanced Scorecard approach, value drivers are used to align the organization to strategy and thereby implement it.

The transition to the Knowledge Economy shows the emergence of a new resource, intangible assets (Daum, 2003; Edvinsson and Malone, 1997; Stewart, 1991). Studies show that, by 2000, intangible assets dramatically shift to the greater part of company value and form the main source of value creation (Daum, 2003; Edvinsson, 2002; Lev, 2001; Lev and Daum, 2004; Lev and Gu, 2016; Stegmann, 2009). Strategy maps (Kaplan and Norton, 2004) are an overview about the firm grounded on intangible assets. There are several definitions of intangible assets. In financial accounting, IAS 38, intangible assets may be classified as customer lists, customer relations, supplier relations, marketing rights, research, development, patents, computer software, databases and trade secrets, trademarks, trade dress, newspaper mastheads, internet domains, video and audiovisual material, mortgage servicing rights, licensing, royalty and standstill agreements, import quotas, franchise agreements. In financial accounting, intangible assets need to be controlled by the entity, whereas in management a broader definition is accepted. Intangible assets may 
be understood as capitals: intellectual capital (Lev, 2001, 2004; Lev and Gu, 2016), which comprises the intangible value of a business, covering its people (human capital), the value relating to its relationships (relational capital), and everything that is left when the employees go home (structural capital), of which intellectual property is but one component. Another type of intangible assets are the activities that precede operations (Damodaran, 2007): research and development, marketing, supply chain management. This type of intangible asset may be a project or series of projects, programs (International Organization for Standardization, 2017; Project Management Institute, 2013). Projects are allocated capital based on a mixture of strategic and financial criteria and in practicing organizations by a project management board which reviews all these criteria (International Organization for Standardization, 2017; Project Management Institute, 2013). In this view, projects are temporary endeavors to create a unique product, service or result. Projects are capital expenditures, allocation or investment. Operations are repetitive efforts to deliver services or results. Their costs are operational expenditure. Intangible assets may explain companies' value (Stegmann, 2009).

The New Economy is shaped as networks (Chesbrough, 2001; Gossain and Kandiah, 1998; Kelly, 1997; Kothandaraman and Wilson, 2001; Moore, 2006; Prahalad and Krishnan, 2008) or eco-systems (Ben Letaifa, 2014; Gossain and Kandiah, 1998; Moore, 2006), where value creation and capture are different from the logic of the Industrial Economy. Business models may be products in traditional value chains or platforms in networks; in this view, business models are a synthesis which highlights traditional value chains, supply side economics, or products when compared to networks, demand side economics, or platforms (Van Alstyne et al, 2016).

The new VUCA environment also impacts financing decisions via real options (Luehrman, 1998). In a certain environment, strategy is a detailed plan for action valued via the net present value of discounted cash flow. In a VUCA world, strategy is a decision tree with several options (Koller et al, 2005, 2010a, 2010b, 2015). These options are modeled using call options or put options (Damodaran, 2010, 2011, 2012).

With Kaplan and Norton (2004), value drivers are the hypotheses that shape strategy. Strategy maps comprise customer value proposition, internal activities, capital resources are non-financial value drivers, while revenue, cost and assets financial value drivers (Kaplan and Norton, 1992, 2004). Business models work at the very early discovery stage in strategy as hypotheses (Blank, 2013; McGrath and MacMillan, 1995; Girotra and Netessine, 2013). Already in 1995, McGrath and MacMillan theorized discovery driven planning: in an uncertain world, stages of discovery and testing hypotheses preceed the business plan, suitable for a certain environment. One way to represent business models is the business model canvas (Osterwalder and Pigneur, 2010). With the business model canvas, a new tool in strategic management 
comprises the value drivers in strategy maps plus customer related drivers - customer segments, customer relationships and customer channels and external resources such as partners. Moreover, business models' canvas is intended to illustrate and explain value creation, proposition and capture (Osterwalder and Pigneur, 2010). The elements of the business model canvas are consistent with the value driver definition as any factor that impacts value creation. A series of articles in Harvard Business Review (Blank, 2013; Bonchek and Choudary, 2013; Casadesus-Masanell and Ricart, 2011; Eyring et al, 2011; Ferry, 2017; Girotra and Netessine, 2013; Grossman, 2016; Kavadias et al, 2016; Johnson et al, 2008; Ladd, 2016; Ovans, 2015; Pisano, 2015; Satell, 2017a, 2017b; Van Alstyne et al, 2016) argue in favor of business models as the new tool to conceptualize competitive advantage, a major form of innovation, one of the drivers of digital disruption and digital transformation, the goal start-ups should produce, a means to fund start-ups later on. Business models, the new tool in strategic management, are managed in internal or external start-ups (Blank, 2013). Start-ups may be defined as (Blank, 2013) a temporary organization designed to search for a repeatable and scalable business model. An alternative definition for a start-up (Ries, 2011) is a human institution designed to deliver a product or a service under conditions of extreme uncertainty (Ries, 2011). At this stage, the product is a pivot (Ries, 2010). The subsequent stage is the execution of the business model, which involves a plan about the how cash flow will be generated. As the cost of developing a digital startup has fallen from approximately $\$ 5$ million in 2000 to $\$ 5,000$ as of 2013 (Capgemeni, 2016), the lean start-up movement is taking the world by storm (Blank, 2013; Girotra and Netessine, 2013; The Global Center for Digital Business Transformation, 2019a, 2019b; Grossman, 2016). Traditionally, venture capital has been used to finance start-ups or business development efforts (Kaplan Financial Limited, 2012a, 2012b). Venture capital is a type of private equity, a form of financing that is provided by firms or funds to small, early-stage, emerging firms that are deemed to have high growth potential, or which have demonstrated high growth (in terms of number of employees, annual revenue, or both). The lean start-up movement is closely tied to venture capital (Blank, 2013). Already since the proposal of open innovation (Chesbrough, 2002), one network business model, venture capital is recommended.

\section{EMPIRICAL EVIDENCE}

\subsection{Key value drivers in siemens' digitalization strategy - about Siemens}

Siemens is a large industrial global European based engineering company founded in 1847. Since then, Siemens has acted as a large company with a portfolio of products that has changed throughout time. In 1998, Siemens has a wide variety of businesses and business types. In 1998, Siemens' portfolio comprises groups in energy, industry, information and communications, transportation, healthcare, lighting, 
household appliances. Since 2010, Siemens has focused its portfolio on key sectors industry, energy, infrastructure and cities (Siemens, 2014d, 2016). In the future, 2020 onwards, Siemens will scale up and will tap adjacent markets. Siemens has large or medium business customers, with whom it engages in contracts that report sales per contract or won orders. Siemens supplies products, services, solutions, capital assets, constructions in customer specific contracts. Siemens is organized in the Managing Board and Supervisory Board. Siemens' Management Board comprises members from Siemens' businesses, regions, corporate functions. Siemens' research and development activities are organized in a Central Technology Department and in business specific departments. Siemens manages customers via key account managers and Siemens Management Consulting. Key account managers are organized on customer markets as third organizational dimension. A Corporate Supply Chain Management organization is responsible for global supply networks, supplier involvement across the product lifecycle, global direct and indirect purchasing contracts, supplier related innovation. Siemens has 298 factories worldwide. Siemens' financial management is centered on Economic Value Added. Performance management bridges strategy, financial management, human resource management. Siemens is a global company, present in 190 countries, with targets to locate business unit management outside Germany, to be active in emerging countries, in innovation hubs, in large business centers.

With reference to the topic of this article, Siemens' value-based management practice is cited by the proponents of the Economic Value-Added model (Stern et al, 2003) as one of the most prominent cases worldwide. Siemens' Economic Value-Added approach has been the topic of a past article at Emerald (Zhao, 2004). Digitalization at Siemens is a Harvard Business Review case study in 2018 (Collins and Junker, 2018). As follows, secondary data about Siemens is explored, analyzed, induced and grouped close to the Siemens original and following key value drivers as criterium to select statements. Whereas the statements belong to Siemens, their selection is based to the relevance of the key value driver approach.

\subsection{Stages in Siemens' digitalization strategy}

Siemens defines digitalization as leveraging digital technology trends for concrete customer benefits, such as key performance indicators (Siemens, 2016c). At Siemens, core technologies electrification, automation and digitalization are types of products, services or solutions Siemens' businesses provide (Siemens, 2018b). In Siemens' digitalization strategy and in a series of other statements, digitalization refers to digital services, vertical software, Internet of Things integration and Webs of Systems. Today, digital platforms all businesses share are Syntalities for digital services, Product Lifecycle Management software for vertical software, Internet of Things consulting and integration (Siemens, 2015a, 2018). Core technologies 
electrification, automation and digitalization are shared by Siemens' businesses and may be an alternative classification to their offerings - products, services, solutions, constructions.

At Siemens, digital services connect Siemens' customers' devices to the digital platform Synalitics and generate data via sensors (Siemens, 2016c). This data is converted into smart data using the smart data principle, a combination of domain, context and device know-how (Siemens, 2016c). Data from Siemens' devices is processed using data analytics, business intelligence and business innovation to customer value. Customer benefits include performance increase, energy saving, cost reduction and risk avoidance and security. Data analytics may refer to the past, be descriptive and inform; may analyze, via diagnostic and predictive analytics; may be prescriptive, describing future decisions and actions (Siemens, 2016c). Vertical software Product Lifecycle Management is another customer offering Siemens classifies as digitalization. This is especially true in the Industry businesses, where Product Lifecycle Management software is a key technology component in Industry 4.0 (Siemens, 2017c). Product Lifecycle Management software is a generic technology adapted to industry, energy and buildings. Internet of Things integration is a management consulting service to Siemens' customers, conducted by strategy consulting Siemens Management Consulting (Siemens, 2018b). It is intended to achieve Internet of Things integration across Siemens' businesses. Cyber-physical systems and Webs of Systems are another digital offering at Siemens, not yet reported but possible to exist again or in the future.

Siemens' digitalization strategy (Siemens, 2015a) consists of the digital foundation, the digital business opportunities thereby created, and tailoring core digitalization technology to businesses and customer industries. Siemens' digital foundation shows the open innovation strategy that comprises business ecoecosystems, internal capabilities and results in the platforms and enablers that underpin digital offerings. Several Siemens other presentations converge to show digitalization offerings are created by blending core technology, business technology and customer industry know-how to achieve a concrete customer proposition, quantified as performance indicator or return on investment. Siemens' achievements in digitalization: digital services, vertical software, cyber-physical systems and Webs of Systems (Siemens, 2016d; 2017d) reflect the core technology plus business technology plus customer industry know-how equals customer value (performance indicators or return on investment) strategy. The platform for digital services, Synalitics, blends analytics know-how, context know-how and domain know-how to deliver customers performance in the form of improved performance, energy savings, cost reductions, risk minimization, quality improvement (Siemens, 2016c). Siemens calls this combination the smart data to business principle (Siemens, 2016c). Vertical software, Smart Innovation including Product Lifecycle Management software, is a core technology adapted to Siemens' businesses and furthermore customer processes and customer industry know-how. Contracts stipulate concrete return on the investment the customer makes. The formula for cyber-physical systems across Webs of Systems combines the same: 
technology with domain context for return on customer investment (Siemens, 2015c, 2016d). Technology comprises smart networked devices (Siemens, 2016). Domain and context comprise domain-specific requirements, cross-domain integration and semantics (Siemens, 2016d). Web of Systems therefore become smart networked systems for industries and critical infrastructures (Siemens, 2016d).

The foundation in Siemens' digitalization strategy is open innovation in core technology, that involves external networks and internal capabilities and creates digital technology platforms and enablers (Siemens, 2015c). Innovation in core technology electrification, automation and digitalization and in business technology is supported by the open innovation strategy. Open innovation is the core group strategy since 2008. Open Innovation is the task of the Corporate Technology Department (Siemens, 2013a). At Siemens, open innovation comprises crowd development, development of user stories and customer insights; validation of existing data-driven service business ideas; development of new datadriven business opportunities (high level); common description of ideas based on proven BizMo ${ }^{\mathrm{TM}}$ methodology; community idea generation, evaluation, discussion and maturation, Siemens' knowledge management system, Corporate Memory, division boards that compile knowledge about past projects as part of Corporate Memory, market information compiled by market boards, project Technoweb, blogs, microblogs, wikis, customer relationship management, corporate memory, the Internet, Internet, publications, TechnoForum, a Web of Knowledge with world-class partners, crowdsourcing of ideas, the Siemens Innovation Fund, eco-systems of partners, innovation producing suppliers (Cozmiuc and Petrisor, 2018a). Open innovation at Siemens is a large topic that may constitute the topic of an individual much larger article (Cozmiuc and Petrisor, 2018a). Siemens' innovation partners form business eco-systems, another pillar of Siemens' digital foundation in its digitalization strategy (Siemens, 2015a). Innovation occurs in several stages: ideation, concept and selection, technology development, market launch (Siemens, 2011). In a technology Siemens uses internally as well, ideation, realization, utilization are stages of product lifecycle (Siemens, 2018a). In 2013, Siemens works in an Enterprise 2.0 mode, that blends network structures with centralized project and portfolio offices (Siemens, 2013b). In 2017, Siemens places its key technology innovation in start-up organization next 47, also called Innovation AG and previously called Siemens Venture Capital. Siemens Venture Capital identifies (Siemens, 2019c) and finances young companies worldwide during their start-up phase and provides established companies with additional capital for their growth plans during the expansion phase. Venture capital is important because it assumes the high risk involved by innovations. Siemens is rated among the top ten venture capital providers in the world. Siemens next 47 supports start-ups along the entire venture lifecycle: incubation, acceleration, growth, transfer and exit (Siemens, 2016a). Next47 will be established as an independent entity which offers freedom to experiment, to innovate and to grow in an early stage of the market 
development (Siemens, 2016a). To that end, Siemens uses all available options: builds, buys and partners to enable tomorrow's successful and profitable companies (Siemens, 2016b). Siemens' dedicated team of experts forms a bridge between the start-up world and the Siemens ecosystem (Siemens, 2016a). Within next 47, there are three organizations that manage start-ups: Technology to Business, Novel Businesses, Technology Accelerator (Siemens, 2016a). Siemens Technology to Business brings externally developed technologies and turns them into innovative Siemens products and technologies. Siemens Novel Businesses takes disruptive business opportunities and transforms them into innovative Siemens businesses. Siemens Technology Accelerator turns innovative Siemens technologies and exists them into innovative businesses outside Siemens. Siemens places future core technology in start-ups, such as artificial intelligence, autonomous machines, connected e-mobility, distributed electrification, blockchain applications. In Siemens' digitalization strategy, internal effort spent for innovation is called digital capabilities (Siemens, 2015a). From a performance management perspective, in Siemens' annual reports, innovation has been measured deliberately in the One Siemens strategy by the annual research and development expenditure; number of research and development staff, in all and by categories; number of patents or similar achievements. In the past decade, Siemens has been ranked by Boston Consulting Group as one of the most innovative companies in the world.

Siemens achieves technology invention in open networks. Siemens complements technology invention with business models. Siemens asserts innovation in the 21st century is created not just by new technologies. Business models also have what it takes to turn the rules of entire industries on their head (Siemens, 2017b). Technology invention and business models are the criteria used by Siemens to select innovation ideas in internal and external idea contests. At the concept and selection stage of the innovation lifecycle, the Open Co-Ideation guideline shapes innovation processes (Siemens, 2014b). According to Siemens, the method has been used since 2009 (Siemens, 2014b). Open Co-ldeation involves several steps to choose ideas (Siemens, 2014b). The first step new ideas by community (guided within predefined framework). The next steps are idea discussion and maturation (supported by expert moderators) and idea pre-selection (through community and expert rating). The fourth step is validation (supported by expert moderators). The next steps are final selection of winner ideas (by high level management jury) and implementation. The Open Co-Ideation concept comprises three parts: the technology view, the business view and the customer value proposition view they create (Siemens, 2014b). The technology view refers to core technology electrification, automation, digitalization.

The business view comprises business intelligence and business innovation (Siemens, 2014b). The customer value proposition view includes business intelligence and business innovation. Customer value proposition may comprise key performance indicators or return on investment. Ideas may also be selected that create value for Siemens. Open Co-Ideation is used by Siemens to approve and finance new ideas 
(Siemens, 2014b). The universal idea language is BizMo, the Siemens framework for business models (Siemens, 2014b). BizMo is the Siemens framework to innovate business models (Siemens, 2014b), and comprises the revenue module (how to generate business volume), the customer module (who are customers), the value proposition module (what is customer value), the investment and finance module (how to obtain capital), the cost module (what are expenses), the delivery module (how to be achieved).

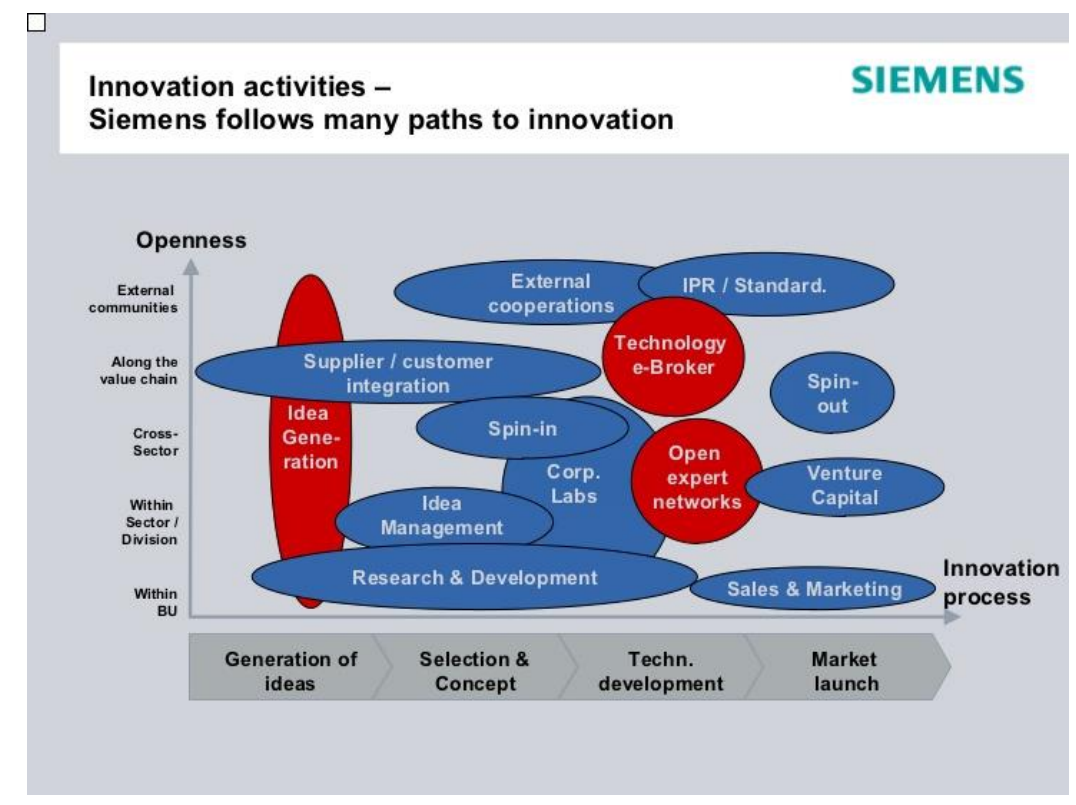

FIGURE 1. SIEMENS' INNOVATION LIFECYCLE

Source: Siemens, 2011

The concept and selection stage are the stage when Siemens decide show to use ideas from its internal or external network. For example, venture capital may be used to spin in start-ups, to scale start-ups into full companies or to sell them to venture funds (Cozmiuc and Petrisor, 2018a). In the past, Siemens used venture capital for special external partnerships but currently only uses it to finance start-ups at all their lifecycle stages (Siemens, 2019c).

As ideas digitalization ideas mature, they become technology platforms and enablers al businesses used. Other sources show Siemens' digitalization strategy as a two-stepped approach (Siemens, 2016c). In Siemens, digitalization strategy, Siemens builds on common technology platforms, that provide the latest technology for all Siemens businesses; reduce technical complexity in the company; leverage synergies through scaling; ensure faster development (Siemens, 2016c). In order to bring this technology to business, Siemens uses customer proximity of operating units to develop applications; this brings knowhow about the large installed bases of products and systems; deep know-how of customer processes and 
challenges; many existing applications that already generate value for customers (Siemens, 2016c). The digitalization strategy enables Siemens to create today's achievements in digitalization, digital platforms all businesses share, like digital services and vertical software. Siemens' digitalization strategy furthermore includes Siemens' customer focus to tailor customer offerings, using Siemens' large installed base and customer access, Siemens' being the trusted partner for critical processes, Siemens' deep vertical knowhow (Siemens, 2015a). Taken together, technology innovation and customer focus enable Siemens to propose customer concrete value, via performance indicators such as increased productivity and flexibility, shorter time-to-market, improved uptimes and lifetimes (Siemens, 2015a). Customer outcomes are included in customer contracts and comprise performance indicators with defined levels, such as higher availability, lower costs, increased performance, more security or return on investment for the whole solution (Siemens, 2016c). Siemens calls this" technology go to market". An even more advanced type of customer contract is network platforms (Siemens, 2016c). Siemens leverages digital technology trends for concrete customer benefits (Siemens, 2016c). Siemens' digital platform, Synalitics, provides tailored digital services to all Siemens businesses (Siemens, 2016c). Product Lifecycle software is essential to Industry 4.0 in manufacturing. The technology may also be used in energy, buildings. Cyber-physical systems and Webs of Systems are key technology in manufacturing, Industry 4.0, and in energy, as energy grids, and in smart cities.

As products, services or solutions are tailored to customers, projects are used. In the Enterprise 2.0 organization (Siemens, 2013b) and in the Siemens innovation lifecycle (Siemens, 2011), as ideas mature, projects are used in a Project and Portfolio Management organization structure (Siemens, 2014c). Projects are contracts with Siemens' customers (Siemens, 2019b) to supply existing products, services and solutions in large or medium-sized orders. Projects have phases, work packages, milestones, plans that show how customer offerings are tailored to individual customers and marketed (Siemens, 2014c). Projects are approved by Portfolio Management Offices (Siemens, 2013b, 2014c) and financed by Siemens Financial Services using debt and equity capital (Siemens, 2019a). Siemens (Siemens, 2014a) shows concrete examples of how smart data was used in projects in various Siemens businesses with individual customers: energy, healthcare, mobility, smart cities.

It is also at this stage Siemens provides Internet of Things integration services. More recently, Siemens Management Consulting has given customer tailoring a new strategic edge (Siemens, 2018b). Siemens Management Consulting Services are customer market specific. They provide a holistic customer offering: consulting, design and prototyping, implementation (Siemens, 2018b). It is a dedicated unit for customer's digital transformation and Internet. Siemens Management Consulting relies on Siemens' global access to customer assets, on its installed base and vertical domain know-how (Siemens, 2018b). 
Siemens' digitalization strategy also involves Siemens' own assessment about its digital readiness. This is Siemens' digital master plan and includes: digital strategy; offering and business models; business plans including investment; go to market sales concept; customers and partners; well-trained resources already mentioned in this article. Digitalization also involves roll out and headquarter support, branding, tailor made digital events, data base for use cases. Siemens' digital foundation transforms Siemens into a digital company (Siemens, 2015a).

\section{CONCLUSIONS}

In summary, Siemens' key value drivers are core technology know-how, business technology know-how, customer industry know-how (intangible assets) and the customer value proposition (key performance indicators or return on investment) of individual products, services and solutions. These value drivers reflect the stages in Siemens' digitalization strategy. The first stage in digitalization is investment in core technology, an intangible asset which has digital platforms and technology inventions as outcome. The platforms are created in open innovation networks or business eco-systems, where start-ups are financed by venture capital. The next decision is to tailor platforms, using business technology know-how (such as manufacturing) and customer industry know-how (such as automotive manufacturing). Once this investment in intangible assets is performed, innovation in digitalization is outcome; so is the product, service, solution. Siemens' digitalization strategy systematically comprises investment in intangible assets to deliver concrete customer value proposition.

In the Open Co-Ideation guideline, business models help turn invention into innovation. Another key value driver is customer value proposition, expressed as performance indicator or return on investment. Siemens approves innovations ideas based on core technology, business technology, business models and concrete customer value proposition. The paper also finds this investment is related to the ideation stage in the innovation life cycle, is placed in networks especially start-ups, is funded using business models specially to shape the customer value proposition and funded by venture capital. The paper also finds this investment is related to the ideation stage in the innovation life cycle, is placed in networks especially startups, is funded using business models specially to shape the customer value proposition and funded by venture capital. At later stages in the innovation lifecycle, approaching the customer contract negotiation, the customer value proposition is enclosed in customer contracts and basis for this negotiation. Siemens changes organizational structure from open networks, especially start-ups to intra-organizational project management and program office. Projects are financed with equity and debt using Economic Value Added as capital budgeting method. 
In conclusion, digitalization and New Economy value-based management tools such as venture capital are included in the overall Economic Value-Added logic. The Siemens example shows how in a large corporation classic value-based management and New Economy updates are compatible. Therefore, the goal of the article is met.

\section{REFERENCES}

Accenture. (2019). Digital transformation turns every business into a digital business, Retrieved April 7th, 2020, from https://www.accenture.com/ro-en/service-digital-transformation.

Arnold, G. (1998). Corporate Financial Management. Pitman Publishing. London.

Ben Letaifa, S. (2014). The uneasy transition from supply chains to ecosystems: The value-creation/valuecapture dilemma. Management Decision. 52(2): 278-295.

Bennet, N., \& Lemoine, G., J. (2014). What VUCA really means for you. Harvard Business Review. January-February 92(1).

Berinto, S. (2014a). A Framework for understanding VUCA, Harvard Business Review, SeptemberOctober.

Berinto, S. (2014b). What VUCA really means for you, Harvard Business Review, January- February.

Black, A., Wright, P, \& Bachman, J. (1998). In search of Shareholder Value. Managing the Drivers of Performance, Pitman Publishing, London.

Blank, S. (2013). Why the Lean Start-Up Changes Everything, Havard Business Review, May.

Bonchek, M., \& Choudary, S. P. (2013). Three Elements of a Successful Platform Strategy, Harvard Business Review, January.

Boston Consulting Group. (2008). Value creators report. Retrieved May 26 th, 2020, from https://www.bcg.com/documents/file15314.pdf.

Boston Consulting Group. (2015a). Industry 4.0: The Future of Productivity and Growth in Manufacturing Industries. Retrieved April 7th, 2020, from

https://www.bcgperspectives.com/content/articles/engineered_products_project_business_industry_40 _future_productivity_growth_manufacturing_industries/?article=2.

CapGemeni. (2013). Digital transformation: a roadmap for billion-dollar organizations, Digital Transformation Review No. 1.

CapGemeni. (2016). The Digital Strategy Imperative: Steady Long-Term Vision, Nimble Execution, Digital Transformation Review No. 9.

Casadesus-Masanell, R., \& Ricart, J. E. (2011), How to Design a winning business model, Harvard Business Review, January-February.

Chesbrough, H. (2001). Assembling the elephant: A review of empirical studies on the impact of technical change upon incumbent firms. Research on Technological Innovation. Management and Policy, 7(1): 1-36.

Collins, D. J., \& Junker, T. (2018). Digitalization at Siemens. Harvard Business School Case 717-428. February 2017 (Revised August 2018).

Copeland, T. E., Koller, T. M., \& Murrin, J. (1994). Valuation: Measuring and Managing the Value of Companies. John Wiley \& Sons, New York. 
Copeland, T.E., Koller. T. M., \& Murrin, J. (2000). Valuation, Measuring and managing the value of companies. Third Edition, John Wiley and Sons, New York.

Cozmiuc, D, \& Petrisor, P. (2018). Innovation in the Age of Digital Disruption: The Case of Siemens, Handbook of Research on Strategic Innovation Management for Improved Competitive Advantage, IGI Global, Hershey, Pennsylvania, USA.

Daum, J. H. (2003). Intangible Assets and Value Creation. Wiley, New York.

Damodaran, A. (2007). Return on Capital (ROC), Return on Invested Capital (ROIC), and Return on Equity (ROE): Measurement and Implications, New York University Stern School of Business, New York.

Damodaran, A. (2010). Applied Corporate Finance. Wiley, New York.

Damodaran, A. (2011). Damodaran on Valuation: Security Analysis for Investment and Corporate Finance. Wiley, New York.

Damodaran, A. (2012). Investment Valuation: Tools and Techniques for Determining the Value of Any Asset. Wiley, New York.

Edvinsson, L. (2002). Corporate Longitude - What You Need to Know to Navigate the Knowledge Economy. Financial Times Prentice Hall, New Jersey, USA.

Edvinsson, L. \& Malone, M. (1997). Intellectual Capital. Harper Business, New York, USA.

Eyring, M., Johnson, M. W., \& Nair, H. (2011). New business models in emerging markets. Harvard Business School, January-February.

Emerald (2020). Measuring Business Excellence. Retrieved April $7^{\text {th }}$, 2020, from https://www.emeraldgrouppublishing.com/products/journals/journals.htm?id=mbe.

Ferry, K. (2017). How Organizations Can Thrive in the Digital Economy. Harvard Business Review, March

Gartner (2019). IT Glossary, Retrieved April $7^{\text {th }}$, 2020, from https://www.gartner.com/itglossary/digitalization/.

Girotra, K., \& Netessine, S. (2013). Business Model Innovation for Sustainability, INSEAD Working Paper No. $2013 / 77 / T O M$.

Gossain, G., \& Kandiah, S. (1998). Reinventing value: The new business ecosystem. Strategy \& Leadership. 26(5): 28-33.

The Global Center for Digital Business Transformation (2019a). Digital vortex. Retrieved April $7^{\text {th }}$, 2020, from http://www.imd.org/dbt/digital-business-transformation/.

The Global Center for Digital Business Transformation (2019b), Orchestrating Transformation. Retrieved April $7^{\text {th }}$, 2020, from https://www.imd.org/research-knowledge/books/orchestrating-transformation/.

Grossman, R. (2016). The Industries that are being disrupted the most by digital, Harvard Business Review, March.

IDC (2017a). Digital Transformation. Retrieved April $7^{\text {th }}, \quad 2020$, from https://www.idc.com/promo/thirdplatform/digitaltransformation.

IDC (2017b). Explore 3rd Platform Transformation. Retrieved April $7^{\text {th }}$, 2020, from http://www.idc.com/prodserv/3rd-platform/.

Institute for Business Value (2011). Digital transformation. Creating new business models where digital meets physical. Retrieved April $7^{\text {th }}$, 2020, from https://www07.ibm.com/sg/manufacturing/pdf/manufacturing/Digital-transformation.pdf.

International Organization for Standardization (2017). ISO 9000:2015. Retrieved April $7^{\text {th }}, 2020$, from https://www.iso.org/obp/ui/\#iso:std:iso:9000:ed-4:v1:en. 
IScoop (2019). Digital transformation: online guide to digital business transformation. Retrieved April 7th, 2020, from https://www.i-scoop.eu/digital-transformation/.

Johnson , M., W., Christensen, C., M., \& Kagermann, H. (2008). Reinventing your business model. Harvard Business Review, December.

Kaplan, R., \& Norton, D. (1992). The Balanced Scorecard - measures that drive performance, Harvard Business Review, January-February.

Kaplan, R., and Norton, D. (2004). Strategy Maps: Converting Intangible Assets into Tangible Outcomes, Harvard Business School Press, Brighton, Massachusetts.

Kaplan Financial Limited (2012a). Financial Management, BPP Learning Media.

Kaplan Financial Limited (2012b). Advanced Financial Management, BPP Learning Media.

Kavadias, S., Ladas, K., \& Loch, C. (2016). The Transformative Business Model, Harvard Business Review, October.

Kelly, K. (1997). New Rules for the New Economy, Wired Magazine. Retrieved April 7th, 2020, from https://kk.org/mt-files/books-mt/KevinKelly-NewRules-withads.pdf.

Koller, T., Debbs, R., \& Huyett, B. (2010). The Four Cornerstones of Corporate Finance. John Wiley \& Sons, New York.

Koller, T., Goedhart, M., \& Wessels, D. (2005). Valuation: Measuring and Managing the Value of Companies. John Wiley \& Sons, New York.

Koller, T., Goedhart, M., \& Wessels, D. (2010). Valuation: Measuring and Managing the Value of Companies. John Wiley \& Sons, New York.

Koller, T., Goedhart, M., \& Wessels, D. (2015). Valuation: Measuring and Managing the Value of Companies. John Wiley \& Sons, New York.

KPMG (1999). A Core Competency Approach to Valuing Intangible Assets, International Symposium Measuring and Reporting Intellectual Capital: Experiences, Issues and Prospects Amsterdam.

Ladd, T. (2016). The Limits of the lean start-up method, Harvard Business Review, March.

Leahy, T. (2000), Making their Mark, Business of Finance, June.

Lev, B. (2001), Intangibles: Management, Measurement, and Reporting, Brookings Institution Press, USA.

Lev, B., \& Daum, J. (2004). The dominance of intangible assets: consequences for enterprise management and corporate reporting. Measuring Business Excellence. 8(1): 6-17.

Lev, B., \& Gu, F. (2016). The End of and the Path Forward for Investors and Managers. Wiley, New York.

Luehrman, T. A. (1998). Strategy as a Portfolio of Real Options. Harvard Business Review, September October.

Madden, B. J. (1999). CFROI Valuation (Cash Flow Return On Investment, A Total System Approach To Valuing The Firm), Butterworth-Heinemann, Oxford, Great Britain.

Madden, B. (2010). Wealth Creation: a Systems Mindset for Building and Investing in Business for the Long-Term, John Wiley and Sons, New York, USA.

Martin, J. D., \& Petty, J. W. (2000). Value Based Management - The corporate response to the shareholder revolution. Harvard Business School Press, Brighton, Massachussets, USA.

McGrath, R., \& MacMillan, I. (1995). Discovery-driven planning, Harvard Business Review, July - August. McTaggart, J., M., Kontes, P.,W., \& Mankins, M. (1994). The Value Imperative, The Free Press.

Moore, J.F. (2006). Business ecosystems and the view from the firm. Antitrust Bulletin, 51(1).

Osterwalder, A., \& Pigneur, Y. (2008). Business Model Generation. John Wiley and Sons. Chichester, United Kingdom.

Ovans, A. (2015). What Is a Business Model?. Harvard Business Review, January-February. 
Pisano, G., P. (2015). You Need an innovation strategy. Harvard Business Review, June.

Prahalad, C.K. \& Krishnan, M.S. (2008). The New Age of Innovation: Driving Co-Created Value Through Global Networks. McGraw-Hill, New York, NY.

Project Management Institute (2013). A Guide to the Project Management Body of Knowledge (PMBOK® Guide), Project Management Institute; Sixth Edition.

Rappaport, A. (1986). Creating Shareholder Value. The Free Press, New York.

Ries, E. (2010). Introduction to Customer Development at the Lean Startup Intensive at Web 2.0 Expo by Steve Blank. Retrieved April $7^{\text {th }}, \quad 2020$, from https:/www.slideshare.net/startuplessonslearned/introduction-to-customer-development-at-the-leanstartup-intensive-at-web-20-expo-by-steve-blank.

Ries, E. (2011). The Lean Startup: How Today's Entrepreneurs Use Continuous Innovation to Create Radically Successful Businesses. Retrieved April $7^{\text {th }}$, 2020, from https://www.amazon.com/LeanStartup-Entrepreneurs-Continuous-Innovation/dp/0307887898.

Satell, G. (2017a). This Program Uses Lean Startup Techniques to Turn Scientists into entrepreneurs, Harvard Business Review, March.

Satell, G. (2017b). The Types of Innovation and the Problems. Harvard Business Review, June.

Siemens (2011). Opening innovation. Retrieved April $7^{\text {th }}, 2020$, from https://www.slideshare.net/heisss/opening-innovation-7436014.

Siemens (2013). Innovation in an Enterprise 2.0. Retrieved April $7^{\text {th }}$, 2020, from https://www.slideshare.net/heisss/innovation-in-an-enterprise-20.

Siemens (2014a). From big data to smart data. Retrieved April $7^{\text {th }}$, 2020, from https://w3.siemens.com/topics/global/en/events/hannover-messe/program/Documents/pdf/Smart-Datato-Business-Michal-Skubacz.pdf.

Siemens (2014b). Open Co-Ideation @ Siemens. An Innovation approach to connecting an organization's knowledge and creativity. Retrieved April $7^{\text {th }}$, 2020, from https://studylib.net/doc/18616093/open-coideation-\%40-siemens.

Siemens (2014c). PM@Siemens. Integrated Project Management. Retrieved April $7^{\text {th }}, 2020$, from http://ipma.it/ipma_/images/E._Delogu_Siemens_Presentation_Evento_ANIMA-ANIMP_03.05.16.pdf.

Siemens (2014d). Siemens annual report, https://www.siemens.com/annual/14/en/download/pdf/Siemens_AR2014.pdf (accessed 2020).

Siemens (2015a). The digital change constant, Retrieved April $7^{\text {th }}, 2020$, from https://www.siemens.com/press/pool/de/events/2015/corporate/2015-09-analyst-

conference/presentation-kayser-e.pdf.

Siemens (2015c). Web of Systems for a digital world. Retrieved April $7^{\text {th }}$, 2020, from https://www.siemens.com/press/pool/de/events/2015/corporate/2015-12-internet-of-

things/presentation-iot-russwurm_web-of-systems-e.pdf.

Siemens (2016a). Corporate Technology. Our central research and development unit. Retrieved April $7^{\text {th }}$, 2020, from https://www.siemens.com/content/dam/internet/siemenscom/global/company/innovation/innovation/corporate-technology/pdf/CT-

Standardpresentation_E_March_2017.pdf.

Siemens (2016b). next47. Retrieved April $7^{\text {th }}, 2020$, from https://www.siemens.com/press/pool/de/feature/2016/corporate/2016-06-next47/presentation-next47e.pdf. 
Siemens (2016c). Siemens Digitalization Strategy \& Sinalytics Platform. Retrieved April $7^{\text {th }}$, 2020, from https://www.siemens.com/digitalisierung/public/pdf/Sinalytics-and-Digital-Services-Presentation.pdf.

Siemens (2016d). We enable digitalization. Retrieved April $7^{\text {th }}, 2020$, from https://slideplayer.com/slide/13046746/.

Siemens (2017a). Digitalization @ Siemens. Retrieved April $7^{\text {th }}, 2020$, from https://www.automationsummit.se/wp-content/uploads/2017/10/7-\%E2\%80\%93-Mimmi-Alladin.pdf.

Siemens (2017b). Innovations. Retrieved April $7^{\text {th }}, \quad 2020$, from https://www.siemens.com/global/en/home/company/innovation/pictures-of-the-future/innovations.html.

Siemens (2017c). Siemens PLM Software: Innovation for the future. Retrieved April $7^{\text {th }}, 2020$, from http://www.ctecno.cat/wp-content/uploads/2015/09/Siemens-PLM-Innovation-for-the-future-keynote-miX17.pdf.

Siemens (2017d). Siemens Vision 2020 - Focus on profitable growth. Retrieved April $7^{\text {th }}, 2020$, from https://www.siemens.com/investor/pool/en/investor_relations/financial_publications/speeches_and_pre sentations/170322_presentation_bofaml_conference.pdf.

Siemens (2018a). Empowering the Digital Transformation via Digitalization within the Integrated Lifecycle. Retrieved April $\quad 7^{\text {th }}$, 2020, https://www.nist.gov/sites/default/files/documents/2018/04/09/3se1_deren_siemens_empowering_dig_ transf_via_digitalization_in_the_integrated_lifecycle.pdf.

Siemens (2018b). Vision 2020+ Shaping the future Siemens. Retrieved April $7^{\text {th }}, 2020$, from https://www.siemens.com/investor/pool/en/investor_relations/financial_publications/speeches_and_pre sentations/q32018/180802_Press_Analyst_Conference.pdf.

Siemens (2019a). Project finance. Retrieved April $7^{\text {th }}, 2020$, from https://new.siemens.com/global/en/products/financing/project-finance.html.

Siemens (2019b). Project Management made by Siemens. Retrieved April $7^{\text {th }}$, 2020, from https://w3.siemens.com/mcms/engineering-consulting/en/services_engineering/projectmanagement/pages/project-management.aspx.

Siemens (2019c). Siemens Venture Capital. Retrieved April $7^{\text {th }}, 2020$, from https://www.startus.cc/company/siemens-venture-capital.

Stegmann, P. (2009). Strategic Value Management: Stock Value Creation and the Management of the Firm. Wiley, New York.

Stern, G. M., Shiely, J. S., \& Ross, J. (2003). The EVA Challenge. Implementing Value-Added in an Organization. Wiley, New York.

Stewart, G. B. (1991). The Quest for Value. Harper Collins.

Van Alstyne, M. W., Parker, G. G. \& Choudary, S. P. (2016). Pipelines, platforms, and the new rules of strategy. Harvard Business Review, April

Wendee, P. M. (2011). A Theory of Value Drivers: a Grounded Theory Study. University of Phoenix, October 2011.

World Economic Forum (2019). An introduction to the Digital Transformation of Industries initiative. Retrieved April $7^{\text {th }}$, 2020, from http://reports.weforum.org/digital-transformation/an-introduction-to-thedigital-transformation-initiative/.

Zhao, F. (2004). Siemens' business excellence model and sustainable development. Measuring Business Excellence. 8(2): 55-64. 